\title{
- Note- \\ Congenital Diverticulum of the Ileum in a Rat
}

\author{
Takashi YAMADA and Tadahiro INOUE \\ Research Center, Taisho Pharmaceutical Co., Ltd., 1-403 \\ Yoshino-cho, Ohmiya-shi, Saitama 330, Japan
}

(Received 8 November 1991/Accepted 28 January 1992)

\begin{abstract}
A congenital diverticulum of the ileum (Meckel's diverticulum), approximately $10 \mathrm{~mm}$ long, was detected in a rat and examined histologically. The histological findings were basically the same as in the ileum. Although Meckel's diverticulum is uncommon in the rat, the present report demonstrated the possibility of discovering new cases. - KEY WORDS : Meckel's diverticulum, rat
\end{abstract}

Congenital diverticulum of the ileum (Meckel's diverticulum), which is caused by persistence of the omphalomesenteric duct in to postnatal life $[7,8,22]$, consists of a small pouch or blind sac. The incidence of this anomaly is high in fowl intestine [8], and many cases have been reported in humans [1, $3,13,18]$, dogs [15], cats [2], pigs [16], horses $[4,11]$, chickens $[6,12,17]$, geese $[9]$ and ducks [5]. Case reports in the rat, however, are rare [10]. An animal model resembling Meckel's diverticulum in humans has been reported in the rat $[21,23]$, mouse [14] and $\operatorname{dog}[19,20]$. This report describes the outline of a Meckel's diverticulum found in the SD rat which had served as a subject in a certain safety assessment study. The animal was a male, 4 weekold, SPF Sprague-Dawley strain rat (Charles River Japan, Inc.). The animal had been given access to a laboratory diet (MF : Oriental Yeast Co., Tokyo) and tap water ad libitum for 4 weeks and given a certain drug orally in the low dose of $5 \mathrm{ml} / \mathrm{kg}$ for 2 weeks. The rat grew normally without any clinical signs of disease, and its body weight was $382 \mathrm{~g}$. No other abnormalities were detected, and Meckel's diverticulum was not observed in the middle or high dose groups. These findings suggested that the Meckel's diverticulum in this report was not attributable to the drug administered. Macroscopically, the Meckel's diverticúlum was about $10 \mathrm{~mm}$ long and $3 \mathrm{~mm}$ in diameter, with a smaller process and a papilla-shaped sac and was located on the antimesenteric aspect of the ileum (Fig. 1, 2). The color of the Meckel's diverticulum and its cut surface were indistinguishable from that of other parts of the ileum. The diverticulum was filled with intestinal contents.

Tissues fixed in 10\% formalin solution were embeded in paraffin, and sections were stained with hematoxylin and eosin. Microscopic examination showed the structure of the Meckel's diverticulum to be similar to that of the ileum (Fig. 3) and to consist essentially of a mucosa, muscular layer and serosa. The mucosa contained villi whose surface was covered with a single layer of columnar epithelium, and there were numerous goblet cells among the epithelial cells (Fig. 4). The lower part of the villi had crypts containing eosinophilic Paneth cells, and there were lymphatic nodules in the lamina propria mucosae. These findings closely resemble the familiar components of the ileum of the normal rats.

\section{References}

[1] Baer, U., Loch, H., and Baukencht, K. J. (1981). Med Welt., 32, 584-586.

[2] Basher, A. and Appleby, E (1982). Vet. Rec., 110, 
407-408.

[3] Baum, S. (1981). Am J. Gastroenterol, 76, 464-465.

[4] Botz, F. and Sieger, A. (1984). Tieraratl Prax, 12, 217-218.

[5] Bourns, T. K. and Ellis, J. C. (1975). Trans R. Soc Trop. Med. Hyg., 69, 382-387.

[6] Branton, S. L., Lott, B. D., Morgan, G. W., and Deaton, J. W. (1988). Poult. Sci.,67, 677-679.

[7] Eguchi, Y. (1985). In Veterinary Embyology., pp. 122-126, Buneido shuppan, Tokyo. (in Japanese)

[8] Emoto, O. and Yamamoto, S. (1974). In Pathological Anatomy of the Domestic Animal., pp. 105-127. Kanehara Shuppan, Tokyo. (in Japanese)

[9] Gajadhar, A. A., Rainnie, D. J., and Cawthorn, R. J. (1986). J. Parasitol, 72, 588-594.

[10] Gupta, B. N. (1973). Lab. Anim. Sci, 23, 426-427.

[11] Hooper, R. N. (1989). J. Am. Vet. Med Assoc., 194, 943-944

[12] Jeurissen, S. H., Janse, E. M., Koch, G., and De Boer, G. F. (1981). Cell Tissue. Res, 258, 119-124.

[13] Jewett, T. C. Jr. and Lebental, E. (1978). Curr. Proble. Pediatr., 9, 1-50.

[14] Khettery, J., Effmann, E., Grand, R. J., and Treves, S. (1976). Radiology., 120, 629-631.
[15] Marshall, W. S. and Hayes, M. J. (1966). Vet. Rec, 79, 483-484.

[16] Muresan, E., Creanga, C., Popa, A., and Ureche, L. (1968). Lucr. Stünt. Inst. Agron Cluj. Ser. Med. Vet. Zooteh, 23-24, 49-54.

[17] Olah, I., Glick, B., and Taylor, R. L. Jr. (1984). Anat. Rec., 208, 253-263.

[18] Robbins, S. L. and Angell, M. (1976). In Basic Pathology., pp. 464-507. W. B. Saunders Company, Philadelphia.

[19] Sager, V. V. and Piccone, J. M. (1981). Radoilogy, 139, 729-732.

[20] Sfakianakis, G. N , George, N ., Anderson, G. F., King, D. R., and Boles, E. T. Jr. (1981). J. Nucl Med, 22, 678-683.

[21] Taylor, A. T. Jr., Alazraki, N., and Henry, J. E. (1976). J. Nucl Med, 1, 470-472.

[22] Yasuda, M., Nishimura, H., Ezaki, K., and Yamamura, H. (1974). In Current Encyclopedia of Surgery, 8 A., pp. 159-191. Kimoto, S. (eds), Nakayama Shoten, Tokyo. (in Japanese)

[23] Yeker, D., Buyukunal, C., Urancioglu, I., Benli, M., and Buyukunal, E. (1984). Eur. J. Nucl Med, 9, 316-319.

\section{$\mathrm{SD}$ ラットにみられた回腸の先天的

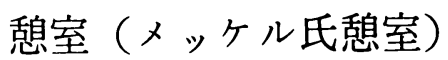

山田隆·井上忠広

大正製薬株式会社総合研究所

$\mathrm{SD}$ 系ラットの回腸にみられた約 $10 \mathrm{~mm}$ の先天的憩 室（メッケル氏憩室）について組織学的検索を行った。 その結果, 組織学的には本例は回腸と同一の構造と機能
を有するものであった。ラットにおけるメッケル氏㮃室 は極めて稀であるが，本報告は今後新たな症例の発見の 可能性を示した。

\section{Explanation of Figures}

Fig. 1. Meckel's diverticulum (arrow)

Fig. 2. Close-up of the Meckel's diverticulum (arrow)

Fig. 3. Longitudinal section of the Meckel's diverticulum A mucosa, muscular layer and serosa are seen in the diverticulum. H. E.stain $\times 2$

Fig. 4. High magnification of the Meckel's diverticulum. Villi, columnar epithelium and goblet cells are seen in this area. H. E. stain $\times 50$ 

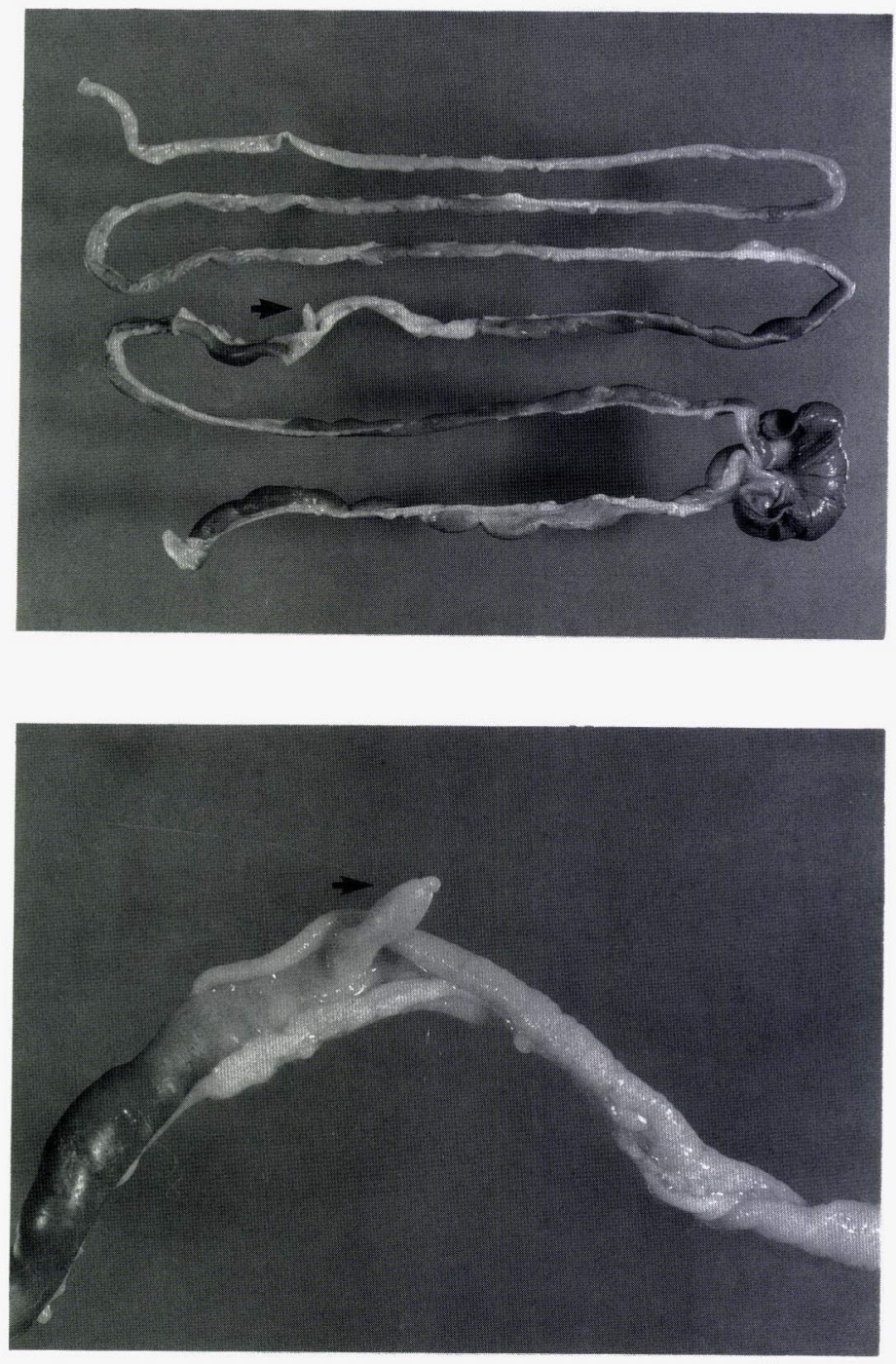

Fig. 1.

Fig. 2. 

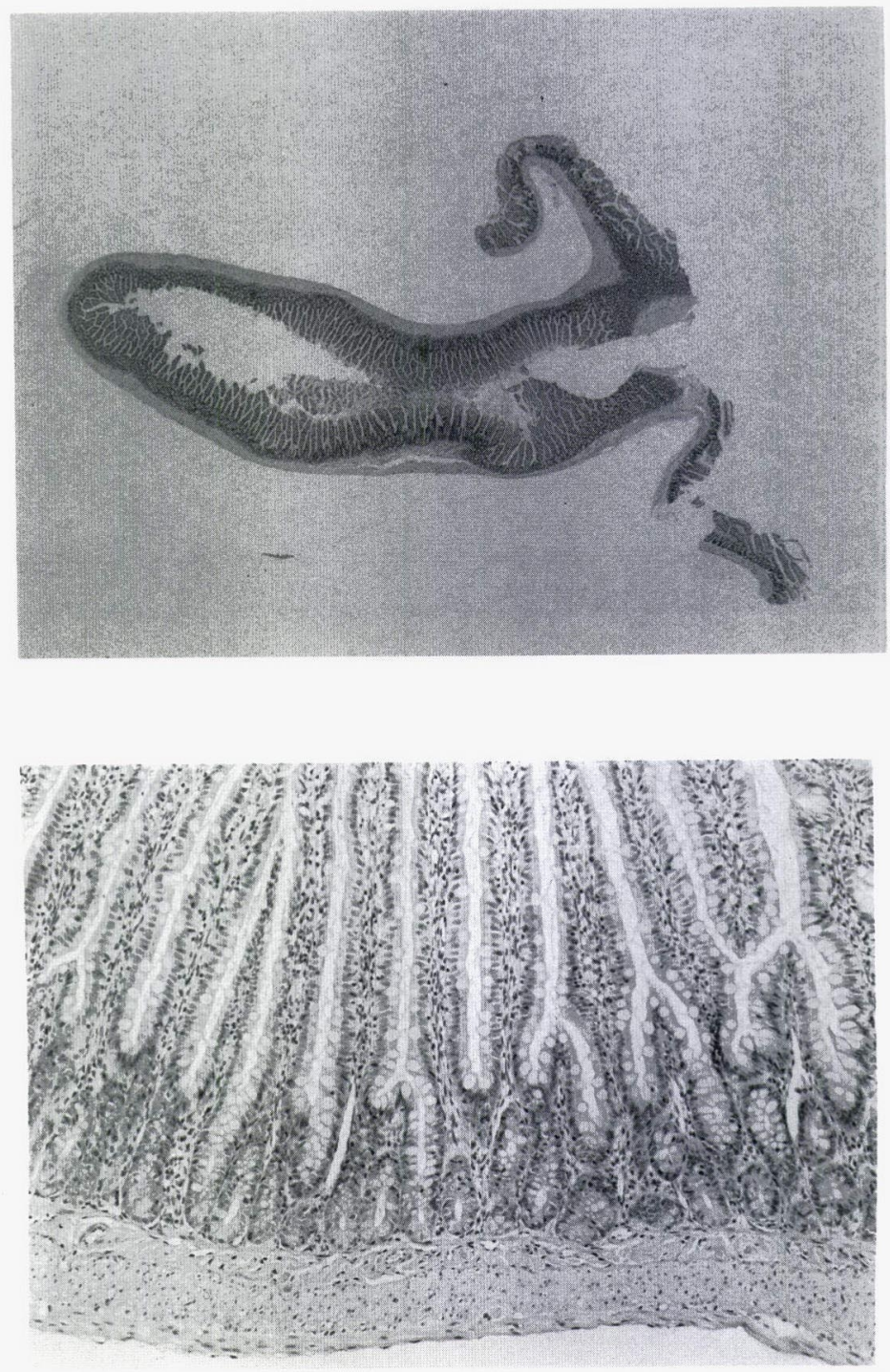

Fig. 3.

Fig. 4. 